\title{
Наноструктурированные магнитные полупроводники для ИК-оптоэлектроники
}

\author{
А.В. Телегин, Б.А. Гижевский, Е.В. Мостовщикова, Ю.П. Сухоруков \\ Институт физики металлов имени М.Н. Михеева УрО РАН, \\ Екатеринбург, 620137, С. Ковалевской 18 \\ тел:+7 (343) 378-3743, факс:+7 (343) 374-5244, эл. почта: telegin@imp.uran.ru
}

DOI 10.34077/RCSP2019-96

Наноструктурированные магнитные полупроводники (МПП) представляют интерес как функциональные материалы с управляемыми оптическими и радиочастотными свойствами. Среди физических способов получения однофазных наноматериалов перспективными являются размол в вибромельнице и пластическая деформация под давлением [1]. Оптические и магнитооптические (MO) методы являются эффективными инструментами изучения особенностей наноматериалов [2]. В тоже время мало данных об особенностях магнитооптических свойств наноструктурированных МПП.

Практический интерес представляют МПП, обладающие прозрачностью в ИК-области спектра и большими магнитооптическими и магнитотранспортными эффектами: шпинели $(\mathrm{Cd}, \mathrm{Hg}) \mathrm{Cr}_{2} \mathrm{Se}_{4}$, манганиты $\mathrm{A}_{1-\mathrm{x}} \mathrm{B}_{\mathrm{x}} \mathrm{MnO}_{3}$, феррит-гранаты и т.д. По специально разработанной технологии были созданы высокоплотные ИК-прозрачные нанокерамики и прессованные многокомпонентные и полимерные гибкие нанокомпозиты [3].

В результате исследований были определены основные особенности электронной структуры и оптических свойств наноструктурированных МПП в сравнении с моно- и поликристаллами, оценена роль размерного фактора, дефектности и восстановительных отжигов в формировании электронных и магнитных свойств наноматериалов [4,5]. Обнаружены эффекты магнитопоглощения и магнитоотражения ИК-излучения в нанокерамиках и нанокомпозитах МПП, сравнимые с пленками и монокристаллами [6,7]. Обнаружен гигантский эффект Фарадея в нанокерамиках ЖИГ [8]. Получен эффект сдвига края фундаментального поглощения в нанокерамике оксидов меди [9]. Показано, что в МПП гигантские МО эффекты наблюдаются и в ТГц области частот [10]. При этом частота модуляции излучения за счет эффекта магнитопропускания в среднем ИК-диапазоне может достигать в МПП порядка $10^{9}-10^{14}$ Гц [11].

Таким образом, высокоплотная нанокерамика и нанокомпозиты могут заменить монокристаллы и позволяют варьировать температурный и спектральный рабочий диапазон МПП. Полученные эффекты быть использованы для создания оптических элементов высокочастотных модуляторов среднего ИК и ТГц диапазона.

Работа выполнена в рамках государственного задания ФАНО России (тема «Спин» № АAАА-А18118020290104-2), при поддержке программы Уро РАН № 18-10-2-37.

\section{Jumepamypa}

[1] Б.А. Гижевский и др. // Петрология. 2012. Т.20, вып.4. С.351-366.

[2] A.V. Telegin et al. // J. Supercond. Nov. Magn. 2012. V.25, Iss.8, P.2683-2686.

[3] А.В. Телегин и др. // Патент на изобретение № 2497166. Бюллетень №30 от 27.10.2013

[4] E.V. Mostovshchikova et al. // Sol. Stat. Phenomena. 2012. V.190, P.683-687.

[5] V.R. Galakhov et al. // J. of Appl. Phys. A. 2015. V.118, P. 649-654.

[6] A.V. Telegin et al. // J. of Appl. Phys. 2013.V 113, №17. P.17A932.

[7] N.N. Loshkareva et al. // JMMM 2013. V.341, P.49-55.

[8] B.A. Gizhevskii et al. // Solid State Phys. 2009. V.51, №.9, P.1836-1842.

[9] Б.А. Гижевский и др. // ЖЭТФ. 2006. Т.129, С.336-342.

[10] T.J. Huisman et al. // Appl. Phys. Lett. 2015. V.106, P.132411.

[11] Ю.П. Сухоруков и др. // Патент на изобретение №2346315. Бюллетень №4 от 10.02.2009 